\title{
ELASTOGRAPHIC ANALYSIS OF THE SUPRASPINATUS TENDON IN DIFFERENT AGE GROUPS
}

\author{
ANÁLISE ELASTOGRÁFICA DO TENDÃO \\ SUPRA-ESPINAL EM DIFERENTES FAIXAS ETÁRIAS
}

\author{
César Rubens da Costa Fontenelle ${ }^{1}$ (1), Márcio Schiefer ${ }^{2}$ (i), Pietro Mannarino ${ }^{1,2}$ (), Isac Borges Lacerda ${ }^{1}$ (1),

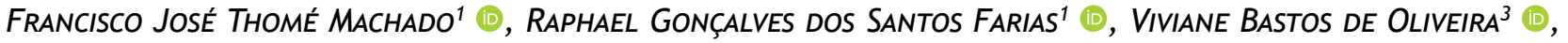 \\ LILIAM FERNANDES DE OLIVEIRA ${ }^{3}$ (1)
}

1. Universidade Federal do Rio de Janeiro, Hospital Universitário Clementino Fraga Filho, Orthopedic Trauma Service, Rio de Janeiro, RJ, Brazil.

2. Universidade Federal do Rio de Janeiro, Department of Orthopedics and Traumatology, Medical School, Rio de Janeiro, RJ, Brazil.

3. Universidade Federal do Rio de Janeiro, Biomed Engineering Program, Rio de Janeiro, RJ, Brazil.

\section{ABSTRACT}

Objective: To compare the mechanical properties of the supraspinatus tendon in different age groups using Supersonic Shearwave Imaging (SSI) elastography. Methods: We evaluated 38 healthy individuals of both genders, 20 being in the range of 20 to 35 years and 18 being over 60 years. The shear modulus of the supraspinatus tendon was measured by SSI elastography, always on the right side. Means between age groups were compared and statistically analyzed using the Shapiro-Wilk normality test followed by the student's t-test and were established as a statistically significant value of $p \leq 0.05$. Results: A statistically significant difference was observed when the mean values of the shear modulus of the supraspinatus tendon of young adults $(23.98 \pm 9.94 \mathrm{KpA})$ were compared with those of older adults (17.92 $\pm 6.17 \mathrm{KpA})$. Conclusion: We found a difference between the means of the shear modulus measured by the SSI elastography, showing a significant decrease of the shear modulus with the chronological age progression. Level of Evidence III, Diagnostic Studies - Investigating a Diagnostic Test.

Keywords: Rotator Cuff. Shear Strength. Aging. Elasticity Imaging Techniques. Diagnostic Imaging.

\section{RESUMO}

Objetivo: Comparar as propriedades mecânicas do tendão supraespinal em diferentes grupos etários, utilizando a elastografia Supersonic Shearwave Imaging (SSI). Métodos: Foram avaliados 38 indivíduos saudáveis de ambos os sexos, sendo 20 na faixa de 20 a 35 anos e 18 acima dos 60 anos de idade. Foi aferido o módulo de cisalhamento do tendão supraespinal por elastografia SSI, sempre do lado direito. As médias entre os grupos etários foram comparadas e analisadas estatisticamente, sendo utilizado o teste de normalidade Shapiro-Wilk seguido do student t-test e estabelecido como valor de significância estatística um $p \leq 0,05$. Resultados: Foi evidenciada diferença estatisticamente significativa quando comparadas as médias do módulo de cisalhamento do tendão supraespinal dos adultos jovens $(23,98 \pm 9,94 \mathrm{KpA})$ com a dos idosos (17,92 \pm 6,17 KpA). Conclusão: Houve diferença entre as médias do módulo de cisalhamento medido pela elastografia com SSI, demonstrando diminuição significativa do módulo de cisalhamento com a progressão da idade cronológica. Nível de Evidência III, Estudos diagnósticos - Investigação de um exame para diagnóstico.

Descritores: Manguito Rotador. Resistência ao Cisalhamento. Envelhecimento. Técnicas de Imagem por Elasticidade. Diagnóstico por Imagem.

Citation: Fontenelle CRC, Schiefer M, Mannarino P, Lacerda IB, Machado FJT, Farias RGS, Oliveira VB, Oliveira LF. Elastographic analysis of the supraspinatus tendon in different age groups. Acta Ortop Bras. [online]. 2020;28(4):190-4. Available from URL: http://www.scielo.br/aob.

\section{INTRODUCTION}

Rotator cuff injuries, especially supraspinatus muscle tendon (SP), are among the most prevalent in upper limbs. ${ }^{1}$ Its etiology is multifactorial, including degenerative, traumatic and inflammatory causes. $^{2}$ Yamamoto et al. ${ }^{1}$ underwent ultrasonography of 1,366 individuals aged between 22 and 87 years (mean age 57.9 years) and observed a high prevalence of rotator cuff injuries, reaching
20.7\%. In addition to being very prevalent, such injuries may disable the individuals, because pain intensity can withdrawal they from sports and work activities. ${ }^{2-4}$

The prevalence of rotator cuff disease increases with age. Sher et al.5 underwent magnetic resonance imaging in asymptomatic individuals and found rotator cuff injuries in $4 \%$ of patients under 40 years old and in $54 \%$ of those aged 60 years or older. ${ }^{5}$ Tempelhof et al. ${ }^{6}$

All authors declare no potential conflict of interest related to this article.

The study was conducted at the Universidade Federal do Rio de Janeiro.

Correspondence: Márcio Schiefer. Rua Nóbrega, 62, apto. 602, Niterói, RJ, Brazil, 24220320. marcioschiefer@hotmail.com

Article received on 09/29/2019, approved on 12/12/2019. 
carried out shoulder ultrasonography of 411 asymptomatic volunteers and found a global prevalence of rotator cuff injury of $23 \%$. This study also reported that the prevalence of this injury increased with age, with $13 \%$ of the individuals with 50 years or older, $20 \%$ in the sixth decade and $31 \%$ in the seventh decade. ${ }^{6}$

Although magnetic resonance imaging is the most widespread imaging method for assessing changes in rotator cuff tendons, elastrography has been shown to be as effective as the first in diagnosis and characterization of these alterations. ${ }^{7,8}$ In a wide-ranging literature review, Washburn et al. ${ }^{9}$ showed that elastography was used in studies of various structures, including the calcaneus, patellar, quadriciptal and rotator cuff tendons. ${ }^{9}$

There are two main modalities of elastography: compression (EC) and shear (ES). ES provides noninvasive estimation of tissue mechanical properties. The technique involves a mechanical disturbance in the tissue with an impulse of forces generating a shear wave, visualizing the displacements of tissue and then estimating the speed of the local shear wave (LSW), estimating the "flight time" of this wave. Soft tissue LSW measurements can be interpreted as an indirect evaluation of the shear modulus. ${ }^{10}$

When compared to isolated ultrasonography, ES potentially increases the sensitivity and diagnostic accuracy of tendinopathies, in addition to detecting pathological changes earlier, enabling the prediction of which tendons are at risk of injury and evaluation of the recommended treatments. ${ }^{11}$

\section{Objective}

This study aims to compare mechanical properties of the supraspinatus tendon in two distinct age groups, using the measurement of the tendon shear modulus by elastography.

\section{MATERIALS AND METHODS}

\section{Sample}

This study had the ethical guidelines analyzed by the Research Ethics Committee of the Hospital, with approval recorded by The Embodied Opinion No.1,674,064 of August 8, 2016. The volunteers were recruited by convenience sampling and 38 participants were divided into two groups: one of young adults aged between 20 and 35 years $(n=20)$ and the other for older adults over 60 years of age $(n=18)$. All subjects agreed to participate in the study signing a free and informed consent form. The groups are clearly distinct from each other. Studies aforementioned show that the prevalence of rotator cuff ruptures is low in under 40 years old individuals and high in those over 60 years of age. This fact was used as criterion for defining age groups.

Anamnesis and physical examination were performed in the candidates, and presenting the right upper limb as dominant was the inclusion criteria. Patients with current or previous shoulder symptoms, those with a history of diseases and/or previous shoulder surgeries, as well as those with known systemic disease were excluded. Patients with ultrasound evidence of supraspinatus rupture were also excluded.

\section{Elastog raphy}

For the shear modulus collection, the equipment (Figure 1) Aixplorer, v9 (Supersonic Shearwave Imaging, Aix-in-Provence, France), with Super Linear Transducer TM SL 10-2, width of 40mm, 256 pizoelectric elements, operating in the ranges of 2 to $10 \mathrm{MHz}$ and lateral resolution of $-6 \mathrm{~dB}: 0.3 \mathrm{~mm}$ was used. The participants were placed in the sitting position, with the back of the right hand resting on the lumbar region, to evidence the supraspintus tendon, with the left upper limb extended along the body, hips and knees flexed at $90^{\circ}$ and feet supported to the ground (Figure 2). ${ }^{12}$ The volunteers kept their muscles relaxed throughout the examination.

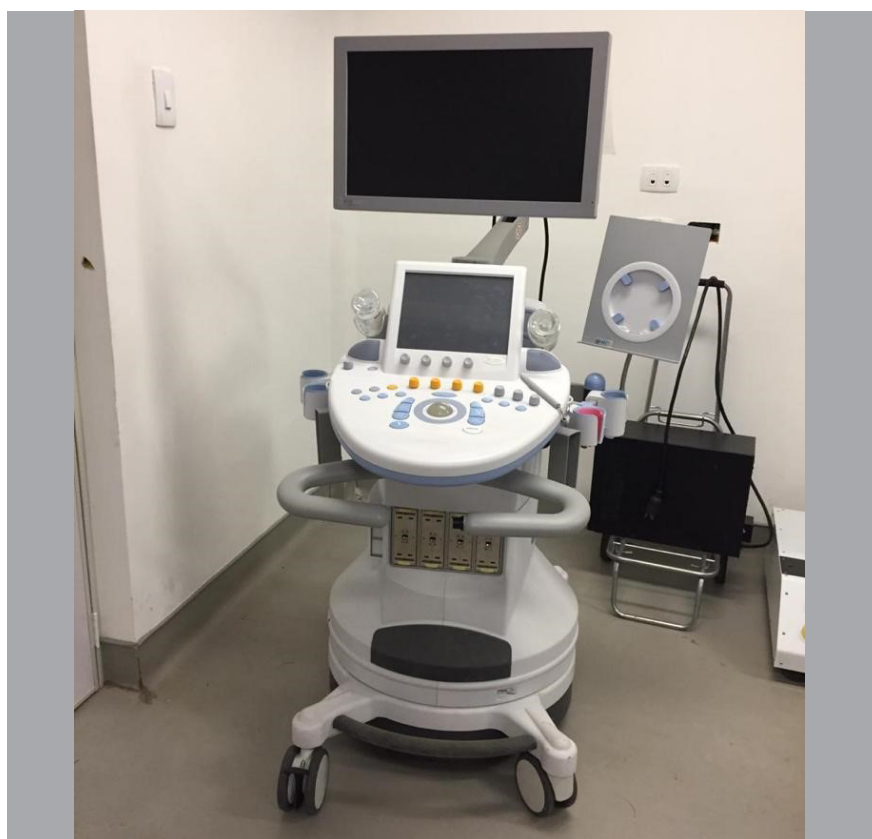

Figure 1. Ultrasound device with elastrography imaging activation mode. Aixplorer, v9 (Supersonic Shearwave Imaging, Aix-in-Provence, France). Source: photo archive of the service.

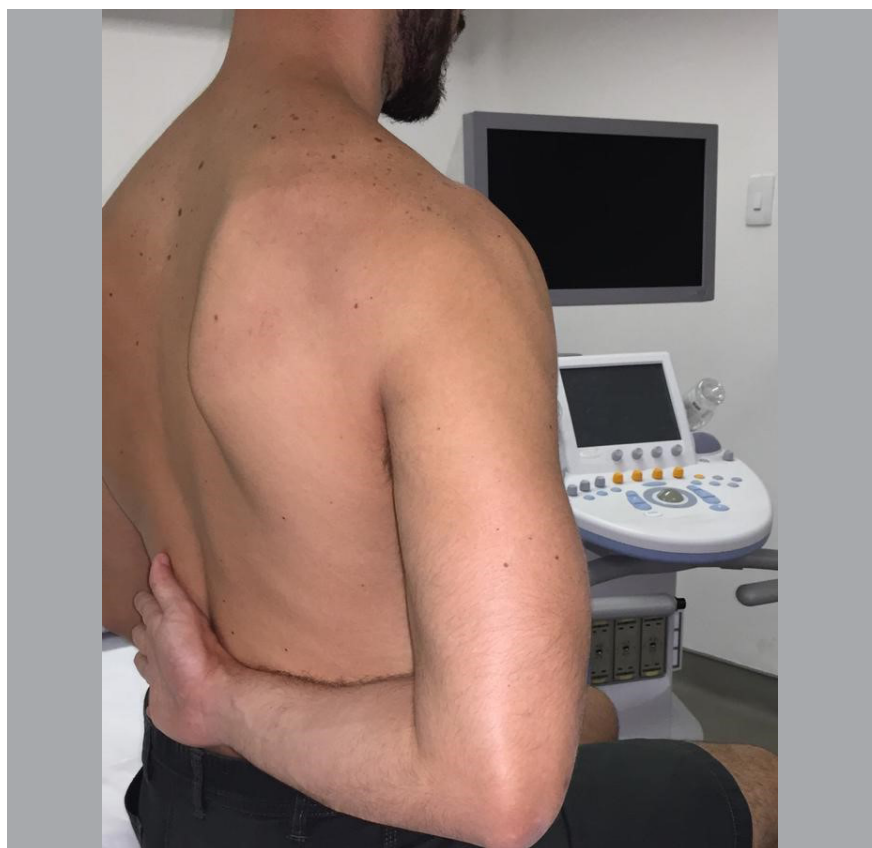

Figure 2. Patient's exam positioning, sitting, with the back of the right hand resting on the lumbar region.

An experienced radiologist in the acquisition of musculoskeletal ultrasound images acquired the images using the transducer longitudinally to the fibers, adopting minimal compression and gel for the best acoustic coupling (Figure 3). A total of three images were acquired to determine the reliability of the method..$^{12}$ Before activating the elastography mode, supraspinatus tendon was assessed for its integrity and the best ultrasound image was chosen. Then elastographic mode was activated, with the elastogram in the range of $0-800-\mathrm{kPa}$. A rectangular, mapping area was selected, demonstrating the tendon boundaries and surrounding structures, positioned in the central region of the tendon (Figure 4). ${ }^{13}$ 


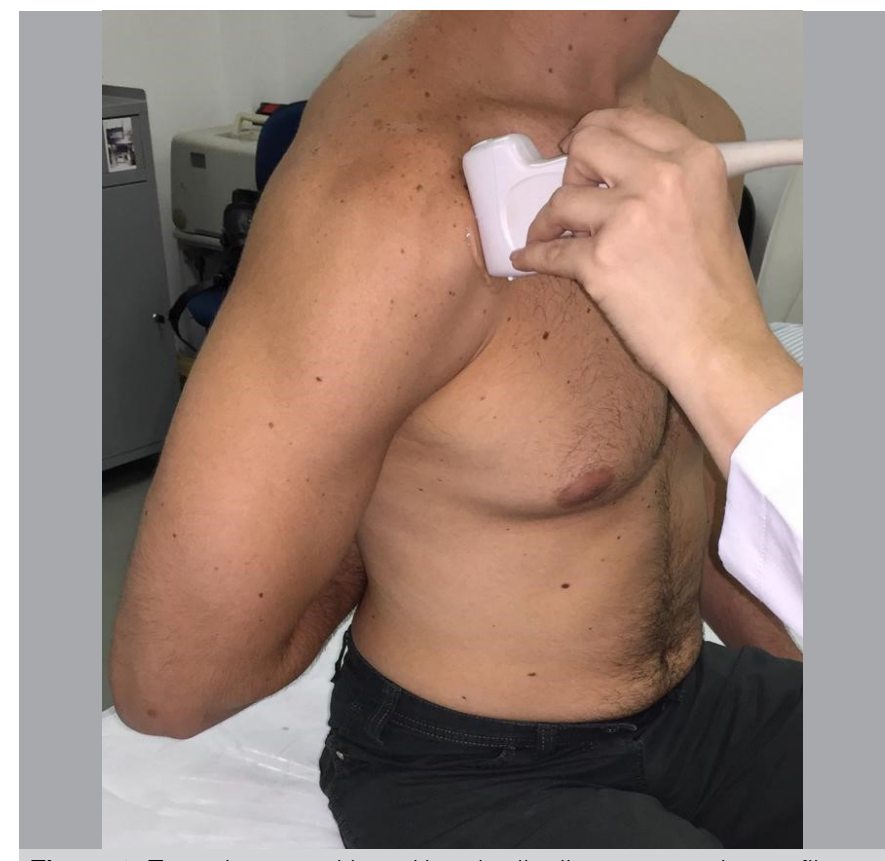

Figure 3. Transducer positioned longitudinally to supraspinatus fibers.

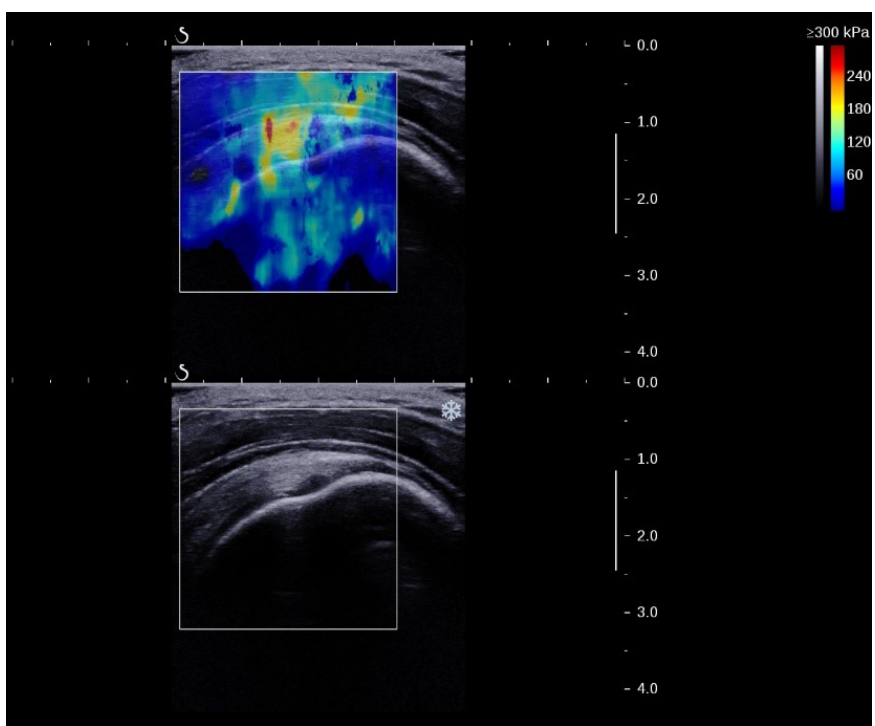

Figure 4. Elastographic image of the supraspinatus tendon, measured in kilopascal $(\mathrm{kPa})$.

Image processing was implemented in a MATLAB routine (Mathworks, Massachusetts, USA), to estimate the shear modulus, measured in kilopascal ( $\mathrm{kPa})$. In this routine, a circle was manually traced in the mapping area, defining the central region of the tendon as a region of interest. The shear modulus was obtained from each region of interest in each image.

\section{Statistical analysis}

Intraclass correlation coefficient $\left(\mathrm{ICC}_{2,1}\right)$ was applied to evaluate the measurements reliability performed on the same day. The Shapiro-Wilk normality test was performed. After confirming the normality of the shear modulus, Student t-test was performed for independent samples comparing means of both young and older adults groups, as well as for the comparison between women and men. All statistical treatment was performed by the commercial package GraphPad Prism 5.0 (Graphpad software inc., USA) with 5\% statistical significance.

\section{RESULTS}

$I C_{2.1}$ estimation indicated reliable measurements (Table 1). A significant difference was found between the means of the supraspinatus tendon shear modulus of youth groups when compared to the older adults ( $p=0.033$ ) (Figure 5). The mean age in the groups of young and older adult was, respectively, 28.05 and 67.9 years. The group of young individuals was composed of four women and 16 men, while the older adults group was composed of 11 women and seven men. There was no significant difference in shear modulus found in women and men ( $p=0.891)$ (Figure 6$)$.

Table 1. Results of the calculation of the intraclass correlation coefficient (ICC) performed using a single rater, absolute agreement and two-way mixed effect model.

\begin{tabular}{c|c|c|c|c|c}
\hline \multirow{2}{*}{ Measure } & \multirow{2}{*}{$\begin{array}{c}\text { Intraclass } \\
\text { correlation } \\
\text { coefficient }\end{array}$} & \multicolumn{2}{|c|}{$\begin{array}{c}95 \% \text { confidence } \\
\text { interval }\end{array}$} & \multicolumn{2}{|c}{ F Test } \\
\cline { 3 - 6 } & Inferior Limit & $\begin{array}{c}\text { Superior } \\
\text { Limit }\end{array}$ & Value & P value \\
\hline Shear Modulus & 0.726 & 0.452 & 0.863 & 3.652 & $<0.001$ \\
\hline
\end{tabular}

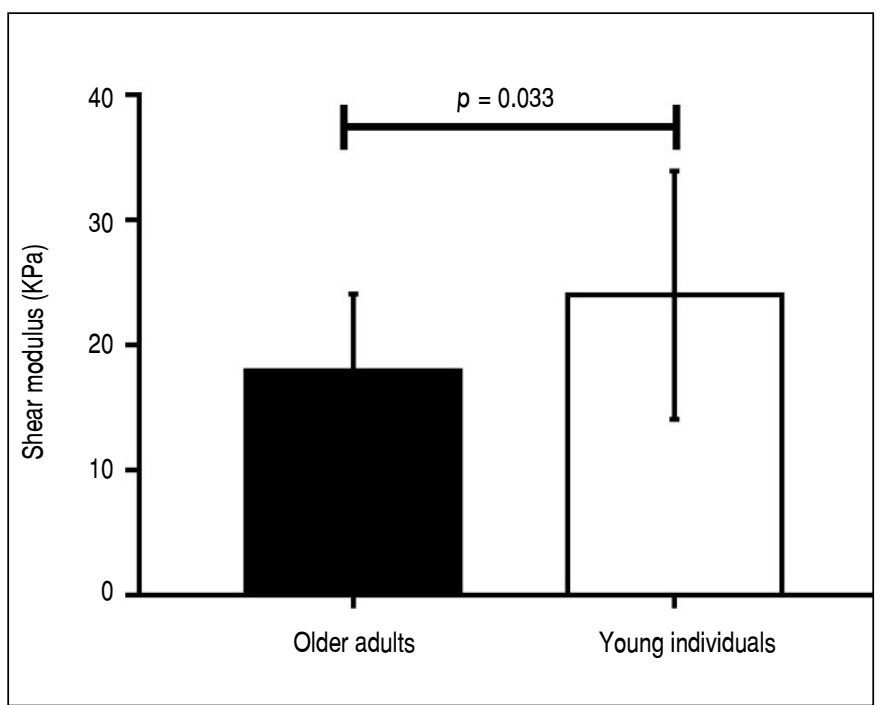

Figure 5. Mean and standard deviation of the shear modulus of older adults and young individuals $(p=0.033)$

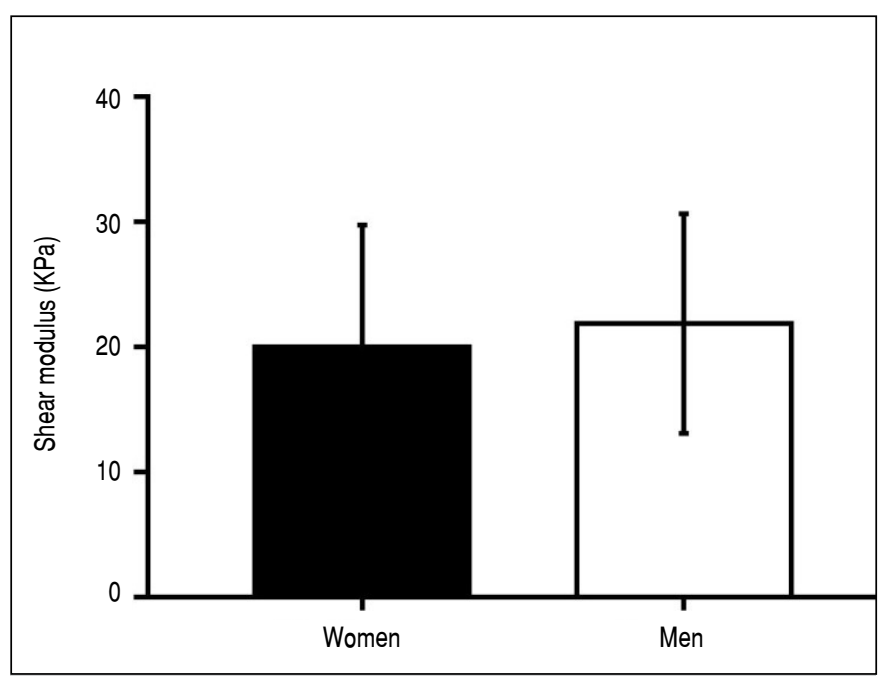

Figure 6. Mean and standard deviation of the shear modulus of women and men. 


\section{DISCUSSION}

This study showed that the supraspinatus tendon shear modulus varies with advancing age. In fact, younger patients, between 20 and 35 years of age, presented a mean shear modulus of $23.28 \pm 9.94 \mathrm{kPa}$, higher than in the group over 60 years of age, which was $17.92 \pm 6.17 \mathrm{kPa}$. Thus, supraspinatus tendon was shown to have a larger, firmer shear modulus among young patients, while in older adults the tendon was less rigid. In fact, with aging, rotator cuff tendons undergo structural changes, such as loss of fibrillar pattern and microruptures, which decreases their compressive strength. ${ }^{14}$ Consequently, the compression exerted by the transducer will cause greater tissue deformation, which was measured by the smaller tendon shear modulus in the group of individuals over 60 years of age. This finding agrees with previous studies. In a cadaveric study, Klauser et al. ${ }^{15}$ observed a correlation between histological and sonographic findings of calcaneus tendons. They observed that the progression of tendon degeneration was accompanied by the "softening" of the tendon to elastography. Studies about supraspinatus tendon, such as ours, also revealed that degenerative tendinopathy is associated with greater capacity of tendon deformation during elastographic evaluation. ${ }^{16-19}$ On the other hand, Baumer et al. ${ }^{20}$ evaluated the influence of age on supraspinatus tendon shear modulus in individuals of different ages and observed that older individuals had stiffer tendons. However, unlike our study, the measurement was carried out in the intra-muscular portion of the tendon, which does not allow the isolated evaluation of the tendon itself, but also involves the muscle belly itself. In a study that correlated elastographic results with magnetic resonance findings, Lee et al. ${ }^{21}$ also observed greater stiffness in tendons with tendon disease. However, differently from our study, the elastographic technique was based on the stretch ratio (strain ratio), in which the tendon elasticity is measured by taking the elasticity of another tissue as a reference, which may generate less accurate results.

A study with cadavers showed that aging can alter biomechanical properties of the myotendinous unit of the rotator cuff. ${ }^{8}$ However, the identification of these changes in vivo is not yet well established. Although MRI is the most widely applied method to assess rotator cuff injuries, it is not able to provide accurate information on the mechanical properties of tendons. In this context, elastography can help in the evaluation of such properties. Lee et al., ${ }^{21}$ in 2015 , showed that elastographic findings correlate with MRI findings in patients with rotator cuff tendinosis, but they did not include patients with tendon rupture. In 2014, Seo et al., ${ }^{22}$ compared the results of elastography with those of MRI and ultrasonography, finding a good correlation between methods. In 2017, Krepkin et al., ${ }^{23}$ conducted a pilot study comparing MRI images obtained on T2 with the findings of shear wave elastography, observing good correlation. In relation to MRI, elastography has some additional advantages. Besides being also a noninvasive method, it is easy to perform, relatively inexpensive and it can be carried out with the patient in a comfortable position, being more easily tolerated by them. Furthermore, elastography proved to be a reproducible method in different studies. ${ }^{20,24}$

The evaluation of the tendon mechanical properties can bring important information and practical implications. Extensive rotator cuff injuries may be irreparable and some prognostic factors are useful to identify these injuries, among which, patient's age, size of the injury, duration of symptoms, acromion-umeral distance less than seven millimeters, reduction of range of motion, muscle strength equal to or less than grade 3, intraoperative difficulties; surgeon's experience, patient expectation; atrophy and fatty infiltration of the muscle belly involved. Such factors are not definitive to determine the possibility and feasibility of repairing a given lesion, even when associated, as this information does not directly relate to the elasticity and/or stiffness of the ruptured tendon. Therefore, the estimation of the shear modulus can add information in determining the repair condition of a rotator cuff injury. ${ }^{8}$ Moreover, some patients may present signs of rotator cuff dysfunction even without having complete injury of one or more tendons. They are patients whose tendons are inserted, but already have some degree of atrophy and fatty infiltration of the muscle belly. These patients may suffer dynamic rise of the umeral head, with secondary subacromial impact and worsening of anatomical tendons conditions. In these cases, by evaluating a mechanical property of the tendon, elastography can also bring valuable information before a tendon rupture occurs. A possible clinical application for this situation would be the preference for reverse to anatomical arthroplasty in a patient with shoulder arthrosis and rotator cuff tendons inserted, although very biomechanically compromised. ${ }^{25}$

Although there is still a lack of standardization to adequately evaluate the reproducibility of the results, elastography is very promising. Notably, tendons may have different elasticity modules. ${ }^{26}$ Therefore, it would be necessary multiple studies like this, in a larger population, divided into age groups, so that a value of the shear modulus could be found for each group and thus quantify and qualify the aging of the tendon based on its stiffness.

Negative points and limitations should be highlighted in this study. The heterogeneous gender distribution between groups may have caused some result bias, since, for example, the mean shear modulus, having been lower in older adults, may have been caused by the fact that there were more female individuals in this group. However, the comparison of the shear modulus between men and women did not show significant difference. Another point would be the fact that SSI elastography is a method that measures only the shear modulus in anisotropic tissues, such as tendinous tissue, not contemplating other mechanical properties of the tendon. However, there is an intimate relationship between shear modulus and tissue stiffness, which allows further analysis of this important biomechanical valence with elastographic data.

\section{CONCLUSION}

The modulus of supraspinatus tendon shear was significantly higher in young people, suggesting deterioration of biomechanical properties of the tendon in older adults.

AUTHORS' CONTRIBUTIONS: Each author contributed individually and significantly to the development of this article. CRCF: work conception, data interpretation and final critical review of the manuscript; MS: data interpretation and writing of the manuscript; PM: conception of work and data interpretation; IBL: selection of volunteers, data collection and review; FJTM: selection of volunteers, data collection and review; RGSF: selection of volunteers, data collection and review; VBO: examinations, statistical analysis and interpretation of results; LFO: work conception, results interpretation and final critical review of the manuscript.

\section{REFERENCES}

1. Yamamoto A, Takagishi K, Osawa T, Yanagawa T, Nakajima D, Shitara H, et al Prevalence and risk factors of a rotator cuff tear in the general population. J Shoulder Elbow Surg. 2010;19(1):116-20.
2. Murthi AM. Rotator cuff tears and cuff tear arthropathy. In: Lieberman JR, editor. AAOS comprehensive orthopaedic review. Rosemont: American Academy of Orthopaedic Surgeons; 2009. p. 817-26. 
3. Hegedus EJ, Goode A, Campbell S, Morin A, Tamaddoni M, Moorman CT 3rd, et al. Physical examination tests of the shoulder: a systematic review with meta-analysis of individual tests. Br J Sports Med. 2008;42(2):80-92.

4. Longo UG, Berton A, Ahrens PM, Maffulli N, Denaro V. Clinical tests for the diagnosis of rotator cuff disease. Sports Med Arthrosc Rev. 2011;19(3):266-78.

5. Sher JS, Uribe JW, Posada A, Murphy BJ, Zlatkin MB. Abnormal findings on magnetic resonance images of asymptomatic shoulders. J Bone Joint Surg Am. 1995;77(1):10-5.

6. Tempelhof S, Rupp S, Seil R. Age-related prevalence of rotator cuff tears in asymptomatic shoulders. J Shoulder Elbow Surg. 1999;8(4):296-9.

7. Yamaguchi K, Tetro AM, Blam O, Evanoff BA, Teefey SA, Middleton WD. Natural history of asymptomatic rotator cuff tears: a longitudinal analysis of asymptomatic tears detected sonographically. J Shoulder Elbow Surg. 2001;10(3):199-203.

8. Giambini H, Hatta T, Rezaei A, An KN. Extensibility of the supraspinatus muscle can be predicted by combining shearwave elastography and magnetic resonance imaging-measured quantitative metrics of stiffness and volumetric fat infiltration: a cadaveric study. Clin Biomech. 2018;57:144-9.

9. Washburn N, Onishi K, Wang JHC. Ultrasound elastography and ultrasound tissue characterisation for tendon evaluation. J OrthopTranslat. 2018;15:9-20.

10. Prado-Costa R, Rebelo J, Monteiro-Barroso J, Preto AS. Ultrasound elastography: compression elastography and shear-wave elastography in the assessment often do in injury. Insights Imaging. 2018;9(5):791-814.

11. Bercoff J, Tanter M, Fink M. Supersonic shear imaging: a new technique for soft tissue elasticity mapping. IEEE Trans Ultrason Ferroelectr Freq Control. 2004;51(4):396-409.

12. Baumer TG, Davis L, Dischler J, Siegal DS, van Holsbeeck M, Moutzouros $\mathrm{V}$, et al. Shear wave elastography of the supraspinatus muscle and tendon: repeatability and preliminary findings. J Biomech. 2017;53:201-4.

13. Gennisson JL, Deffieux T, Fink M, Tanter M. Ultrasound elastography: principles and techniques. Diagn Interv Imaging. 2013;94(5):487-95.

14. Matsen FA 3rd, Titelman RM, Lippitt SB, Wirth MA, Rockwood CA. Rotator cuff. In: Rockwood CA, Matsen FA 3rd, Lippitt SB, Wirth MA, editors. The shoulder. 3rd ed. Philadelphia: Saunders; 2004. p. 812-7.

15. Klauser AS, Miyamoto H, Tamegger M, Faschingbauer R, Moriggl B, Klima G, et al. Achilles tendon assessed with sonoelastography: histologic agreement. Radiology. 2013;267(3):837-42
16. De Zordo T, Chhem R, Smekal V, Feuchtner G, Reindl M, Fink C, et al. Real-time sonoelastography: findings in patients with symptomatic Achilles tendons and comparison to healthy volunteers. Ultraschall Med. 2010;31(4):394-400.

17. Kocyigit F, Kuyucu E, Kocyigit A, Herek DT, Savkin R, Aslan UB. Investigation of biomechanical characteristics of intact supraspinatus tendons in subacromial impingement syndrome: a cross-sectional study with real time sonoelastography. Am J Phys Med Rehabil. 2016;95(8):588-96.

18. Hou SW, Merkle AN, Babb JS, McCabe R, Gyftopoulos S, Adler RS. Shear wave ultrasound elastographic evaluation of the rotator cuff tendon. J Ultrasound Med. 2017;36(1):95-106.

19. Vasishta A, Kelkar A, Joshi P, Hapse R. The value of sonoelastography in the diagnosis of supraspinatus tendinopathy: a comparison study. $\mathrm{Br} \mathrm{J}$ Radiol. 2019;92(1095):20180951.

20. Baumer TG, Dischler J, Davis L, Labyed Y, Siegal DS, van Holsbeeck M, et al. Effects of age and pathology on shear wave speed of the human rotator cuff. J Orthop Res. 2018;36(1):282-8.

21. Lee YH, Kim S, Lim D, Song HT, Suh JS. MR quantification of the fatty fraction from T2-corrected Dixon Fat/Water Separation Volume-interpolated Breathhold Examination (VIBE) in the assessment of muscle atrophy in rotator cuff tears. Acad Radiol. 2015;22(7):909-17.

22. Seo JB, Yoo JS, Ryu JW. Sonoelastography findings of supraspinatus tendon in rotator cuff tendinopathy without tear: comparison with magnetic resonance images and conventional ultrasonography. J Ultrasound. 2014;18(2):143-9.

23. Krepkin K, Bruno M, Raya JG, Adler RS, Gyftopoulos S. Quantitative assessment of the supraspinatus tendon on MRI using T2/T2 mapping and shear-wave ultrasound elastography: a pilot study. Skeletal Radiol. 2017;46(2):191-9.

24. Itoigawa Y, Sperling JW, Steinmann SP, Chen Q, Song P, Chen S, et al. Feasibility assessment of shear wave elastography to rotator cuff muscle. Clin Anat. 2015;28(2):213-8.

25. Steen BM, Cabezas AF, Santoni BG, Hussey MM, Cusick MC, Kumar AG et al. Outcome and value of reverse shoulder arthroplasty for treatment of glenohumeral osteoarthritis: a matched cohort. J Shoulder Elbow Surg. 2015;24(9):1433-41.

26. Coombes BK, Tucker K, Vicenzino B, Vuvan V, Mellor R, Heales L, et al. Achilles and patellar tendinopathy display opposite changes in elastic properties: a shear wave elastography study. Scand J Med Sci Sports. 2018;28(3):1201-8. 